\title{
Effects of Sling and Resistance Rotation Exercises on Pelvic Rotation and Pain in Patients with Chronic Low Back Pain
}

\author{
Dae Hyun Kim, Tea Ho Kim \\ Department of Physical Therapy, College of Rehabilitation Science, Daegu University, Daegu, Korea
}

Purpose: This study compared the different sling and resistance exercises on pelvic rotation during active straight leg raises (ASLR) and on pain in patients with chronic low back pain (CLBP).

Methods: Twenty subjects were divided randomly into a sling group (SG) and a resistance exercise group (REG). Internal oblique (I0), external oblique (EO), rectus abdominis (RA), and rectus femoris (RF) muscle activity; pelvic rotation angle during ASLR; and visual analogue scale, pressure pain threshold were measured. Sling and resistance exercises were then performed for 30 minutes and the measurements taken again.

Results: Both groups showed significantly lower RF muscle activity and significantly higher EO and IO muscle activity $(p<0.05)$. The RA muscle activity decreased significantly in the $S G$, but increased significantly in the REG $(p<0.05)$. The pelvic rotation angle was significantly lower in the SG $(p<0.05)$. The pain press threshold increased significantly in both groups $(p<0.05)$. The visual analogue scale decreased significantly in the SG $(p<0.05)$.

Conclusion: Both exercises appear to be beneficial for modifying the muscle activity and pain control in the intervention of CLBP. On the other hand, the sling was more effective in increasing the pressure threshold than resistance exercise, and the pelvic rotation angle was reduced. Therefore, both exercises can help patients with CLBP change their muscle activity and control pain. CLBP patients should use a sling for short periods of time to learn to reduce the pain and control pelvic rotation.

Keywords: Active straight leg raising test, Back pain, Pelvic rotation angle, Resistance exercises, Sling exercises

\section{서 론}

만성 허리통증은 성인의 $15 \%$, 노인의 $40 \%$ 에서 나타난다. 허리통증으 로 인해 생긴 기능 결손 회복을 위한 치료는 몸통, 하지 근육 부족, 자 세 조절 장애와 같은 문제에 대한 정확한 평가로부터 시작된다.'척추 주변 근육들이 정상적인 기능을 수행 하면 척추가 안정된 지지를 받 게 되어 신체의 원활한 움직임 수행이 가능해진다. ${ }^{3}$ 배바깥빗근은 몸 통의 안정성을 유지하기 위해 지지면 내에 중력중심선을 유지하는데 중요한 역할을 한다. 배바깥빗근은 일반적으로 움직임근으로 분류 되지만 몸에 큰 부하가 주어졌을 경우 안정화를 위해 사용된다. 먼 쪽 분절에서의 움직임 이전에 몸통 안정성을 위해 몸통 분절의 근수 축이 필수적이다. ${ }^{6}$ 이것을 핵심 안정성이라 칭하며 골반 위의 몸통의 위치와 동작을 제어하여 먼쪽 분절에 대한 최적의 생산, 전송 및 제어 를 가능하게 하는 기능이라 하였고, 허리 통증 중재는 이 핵심 안정성

Received Sep 13, 2018 Revised Oct 18, 2018

Accepted Oct 25, 2018

Corresponding author Tea Ho Kim

E-mail hohoho90@naver.com
에 해당하는 배바깥빗근, 배속빗근, 배가로근을 필수적으로 포함해 야한다.6

몸통 회전 저항운동기구(torso rotation machine)를 이용한 운동은 기구를 잡은 팔이 레버의 역할을 하며 회전중심축에서 몸통 회전 힘 을 토크로 변환하여 거리가 멀수록, 저항 부하가 클수록 더 강한 표 면근의 근력을 요구하게 된다. 특히 가로면에서의 저항운동은 배 주 변 근육을 강화하여 몸통 안정성을 유지하는데 큰 도움이 된다.8 가 로면에서의 회전 운동은 몸통 안정성을 유지하는데 필수 근육인 배 바깥빗근, 배속빗근, 넓은등근 등의 근육을 강화하는데 도움이 된다. 슬링 치료는 점진적인 부하 증가, 불안정한 지지면 등을 이용하여 재활초기 통증이 있는 환자를중재하기 유리하다. 또한 스티뮬라 (Stimular, Redcord ${ }^{\circledR}$, Norway)를 이용하여 $20 \mathrm{~Hz}, 40 \mathrm{~Hz}, 80 \mathrm{~Hz}$ 의 진동 상태에서 운동치료를 시행하면 대뇌겉질 활성화에 큰 영향을 미쳐 근육 간 협응과 근 활성도의 증가에 도움이 된다. 특히 불규칙적인 진 
동은 심부 근육 활성도를 크게 증가시키고 통증을 떨어뜨린다. ${ }^{9}$ Neurac 중 treatment: prone bridging 기법은 배곧은근과 엉덩허리근을 주요움직임근으로, 뭇갈래근, 척추세움근, 배속빗근, 배바깥빗근, 넙 다리네갈래근을 핵심근육으로 자극 한다. ${ }^{9}$ 이를 통해 슬링은 허리 통 증 치료에 널리 사용되어 왔다.

능동뻗은발올림검사(active straight leg raising test, ASLRT)는 허리 안정성에 민감한 척도이므로 일반적인 훈련 운동 후 능동뻗은발올 림 동안 측정되는 가로면에서의 골반 회전각이 몸통의 근육 운동 조 절에 어떤 영향을 미치는지에 대한 연구가 진행되어야 한다고 제시하 였다. ${ }^{10}$ 허리 불안정성을 가지거나 허리통증을 가진 사람들은 배 근 육의 활성도가 떨어져 능동뻗은발올림 동안 허리를 축회전하여 보 상작용 하게 되고, 그 결과 골반이 가로면에서 회전하게 된다.10

일부 연구에서는 만성 척추 통증 환자에게 저항 운동 중재가 통증 조절에 거의 영향을 미치지 못하였다고 보고하였다." 재활 초기에 허 리통증 환자에게 일반적인 근력강화 운동에 안정화 운동을 추가한 연구에서도 통증과 장애에 효과를 주지 못하였다. ${ }^{2}$ 일부 연구에서 는 몸통 안정성을 얻기 위한 몸통 강화 운동은 팔다리에 저항 운동 을 수행해야 하고, 가장 효과적은 수단은 불안정한 복부와 허리 근력 운동을 포함해야 한다고 하였다. ${ }^{13}$ 통증 환자를 대상으로 한 저항운 동에 대한 효과로 여러 연구들이 상반된 결과를 제시하고 있다. 또한 허리통증을 위한 회전저항운동과 슬링 운동 중 어떤 운동이 더 효과 적으로 능동뼏은발올림 동안 골반의 회전을 조절한다는 분명한 증 거는 부족한 실정이다. 따라서 본 연구에서 재활 초기에 저항을 통한 근력강화 운동과 슬링 운동이 능동뻗은발올림 동안 가로면에서의 골반 회전 각도 변화와 몸통 근활성도에 어떠한 영향을 미치는지 비 교하고자 한다.

\section{연구 방법}

\section{1. 연구대상}

본 연구의 대상자는 $\mathrm{D}$ 시에 위치한 $\mathrm{OO}$ 정형외과의원의 외래 환자 중 정형외과 전문의로부터 만성 허리통증을 진단 받은 환자 30 명으로 하였다. 일반적인 특성은 Table 1에 제시하였다.

Table 1. General characteristic of participants

\begin{tabular}{lccc}
\hline Variables & SEG $(\mathrm{n}=15)$ & REG $(\mathrm{n}=15)$ & $\mathrm{p}$ \\
\hline Gender $(\mathrm{M} / \mathrm{F})$ & \multicolumn{1}{c}{$7 / 8$} & $8 / 7$ & \\
Age $($ mean $)$ & $34.93 \pm 8.26$ & $35.34 \pm 7.67$ & 0.731 \\
Height $(\mathrm{cm})$ & $167.31 \pm 7.54$ & $166.98 \pm 9.42$ & 0.592 \\
Weight $(\mathrm{kg})$ & $66.67 \pm 9.87$ & $67.15 \pm 7.81$ & 0.462 \\
BMI $\left(\mathrm{kg} / \mathrm{m}^{2}\right)$ & $25.67 \pm 2.24$ & $24.89 \pm 1.83$ & 0.754 \\
\hline
\end{tabular}

SEG: sling exercise group, REG: resistance exercise group.
모든 연구대상자들은 본 연구의 취지와 내용을 충분히 숙지하고 헬싱키 선언의 윤리적 원칙에따라 연구 참여에 자발적 동의를 한 자 로 선정하였다. 3 개월 이상의 만성 허리통증을 진단 받은 자, 전정계 손상이나 시력 장애가 없는 자, 독립적인 보행이 가능한 자, 과거 허리 관련 수술을 한 적이 없는 자를 대상자로 선정 하였다.

대상자는 봉투 안에 슬링군과 부하저항운동군이라고 적힌 종이 를 넣고 순서대로 뽑는 봉투법을 이용하여 저강도 운동을 실시하는 슬링운동군과 고강도 운동을 실시하는 부하저항운동군으로 무작 위 배정하여 분류하였다.

\section{2. 실험방법}

\section{1) 중재방법}

(1) 슬링운동

슬링을 이용한 운동 프로토콜은 Gitle9의 Neurac에 제시된 엎드린자 세의 한쪽 교각운동(unilateral prone bridge)을 기준으로 구성하였다. 대상자는 먼저 배꼽 아래에 $20 \mathrm{~cm}$ 높이의 쿠션을 두고 엎드린 자세를 취하였다. 팔꿈치를 $90^{\circ}$ 로 굽힌 후 어깨관절 내밈을 유지하였다. 우측 정강뼈 거친면을 오목위팔관절 중심부 높이의 슬링에 걸어 왼쪽 다 리를 오른쪽 다리와 같은 높이만큼 들어올려 유지하면서 배를 들어 올렸다. 허리앞굽이가 줄어들면 다시 처음 자세로 천천히 돌아오게 하였다. 이 운동 수행이 어려운 상태의 대상자에게는 탄력 밴드를 이 용하여 부하를 줄여주고, 세트 수가 반복 될 때마다 수행 가능한 부 하량만큼 점진적으로 부하를 늘렸다. 통증이 없는 범위 내에서 중재 하였다. 중재 도중 통증이 생기면 물리치료사의 관리 하에 통증 없이 수행 가능한 단계로 부하를 조절하였다. 오른쪽 다리를 슬링에 걸고 15 세트 운동 후, 왼쪽 다리를 슬링에 걸고 15 세트를 시행하였다. 1세 트에 4 회 실시하였으며, 운동 간 휴식은 20 초로 하였다. 운동 중재에 는 총 30 분이 소요되었으며, 운동 중재가 종료된 후에는 사후 측정 전 3 분의 휴식시간을 가졌다.

\section{(2) 부하저항운동}

부하저항운동은 몸통 회전 저항 운동 기구(torso rotation machine)를 이용하여 실시하였다. 기구의 의자에 앉은 후 가슴 패드를 가슴 윗부 분에 맞춰질 수 있도록 의자를 조절하였다. 머리 위에 있는 회전축을 조절한 후, 중량을 선택하였다. 중량은 총 자기 체중의 $20 \%$ 에서부터 시작하여 세트마다 무게를 점진적으로 증가시켰다. 통증이 없는 범 위 내에서 대상자가 가능한 강도의 무게까지 증가시켰다. 중재 도중 통증이 생기면 물리치료사의 관리 하에 통증 없이 수행 가능한 낮은 단계의 부하로 조정되었다. 가슴 패드에 상체를 밀착한 후, 손잡이를 잡게 하였다. 몸통을 회전축의 반대측으로 회전시킨 후, 천천히 되돌 아 오면서 반복하였다. 허리를 무리하게 돌리거나 보상작용을 하지 
않도록 물리치료사의 감독하에 중재하였다. 1 세트에 4 회를 실시하였 으며 운동 간 휴식시간은 20 초로 하였다. 한쪽의 운동을 15 분 한 후 반대측의 운동을 실시하였다. 운동은 총 30 분이 소요되었으며, 종료 된 후에는 사후 측정 전 3 분의 휴식시간을 가졌다.

\section{2) 측정도구 및 평가방법}

각 운동의 효과를 알아보기 위하여 중재 전후에 배 근육 근활성도, 가로면에서의 골반 회전 각도, 허리 압통 역치와 시각통증척도를 평 가하였다. 모든 대상자의 실험 전후 측정은 한 명의 물리치료사에 의 해 측정되었다. 두가지 운동 군 모두 사전 측정을 하고 1 회 30 분 중재 이후사후측정을 하였다.

\section{(1) 근활성도}

오른쪽 다리의 능동뻗은발올림 동안 대상자들의 오른쪽 배속빗근, 왼쪽 배바깥빗근, 배곧은근, 오른쪽 넙다리곧은근의 근활성도를 측 정하기 위하여 표면 근전도 검사 기기(TeleMyo DTS, Noraxon EMG, USA)를 사용하였다. 근전도 측정 동안 발생할 수 있는 잡음을 제거하 기 위하여 전극 부착 부위를 면도 하고 알코올 솜으로 소독을 하였 다. 표면 근전도 안내지침에 따라 각 근육 부위에 $1.5 \mathrm{~cm}$ 간격으로 표 면전극(Ag-AgCl, Bioprotech, Wonju, Korea)을 부착하였다.14 전극은 대 상자의 왼쪽 배바깥빗근, 오른쪽 배속빗근, 배곧은근, 오른쪽 넙다리 곧은근에 부착하였다. ${ }^{15}$ 대상자의 배속빗근, 배바깥빗근과 배곧은근 의 기준 값을 구하기 위해 무릎 굽히고 바로 누운 자세에서 3 초 동안 테이블에서 약 $8 \mathrm{~cm}$ 양측 발을 들어올려 실효평균값을 구하고, 특정 동작 근수축의 기준 수축값 $(\% \mathrm{RVC})$ 을 구하였다. ${ }^{16}$ 대상자의 넙다리 곧은근의 기준 값을 구하기 위해 바로 누운 자세에서 두 다리를 편 후 오른쪽 다리를 지면에서 $15 \mathrm{~cm}$ 들어올리고 3초 동안 유지하여 실 효평균값을 구하고, 특정 동작 근수축의 기준 수축값(\%RVC)을 구하 였다. ${ }^{17}$

능동뻗은발올림 동안 각 근육의 근전도 측정값을 구하기 위해 대 상자를 바로 누운 자세에서 능동적으로 지면에서 오른쪽 다리를 $20 \mathrm{~cm}$ 들어올린 후 5 초 유지하고 내리게 하였다. ${ }^{10} 3$ 번 측정하여 평균 값을 사용하였다. 능동뻗은발올림 동안 측정된 각 근육들의 제곱근 평균제곱값을 선행 연구에서 제안한 자세에 대한 백분율 $(\% \mathrm{RVC})$ 로 환산하여 결과를 분석하였다.

근전도 측정을 위해 20-450 Hz의 대역통과 필터(band-pass filter)와 $60 \mathrm{~Hz}$ 의 노치 필터(Notch filter)가 사용되었다. ${ }^{18} 1,000 \mathrm{~Hz}$ 의 표집률 (sampleing rate)이 적용되었다. 근전도 측정값은 전용 소프트웨어(MyoResearch XP Master 1.06 software, Noraxon, USA)를 사용하였다. 측정 된 근전도 신호는 제곱근평균제곱(root mean square, RMS)으로 변환 하였다.
(2) 골반회전각도

능동뻗은발올림 동안 대상자들의 가로면에서의 골반 회전 각도를 측정하기 위하여 동작 분석 장치(motion biofeedback device, Relive, Korea)를 사용하였다. 대상자는 바로 누운 자세에서 왼쪽 위앞엉덩뼈 가시와아래앞엉덩뼈가시 사이에 동작 분석 장치를 밴드로 고정시켰 다. 골반의 회전 각도는 근전도가 측정되는 능동뻗은발올림 동안 동 시에 측정되었다. ${ }^{10} 3$ 번의 측정하여 평균값을 사용하였다.

\section{(3) 압통역치}

대상자들의 중재 전후 허리 압통 역치를 측정하기 위하여 압통 역치 측정 기기(algometer commander, JTECH, USA)를 사용하여 측정을 하였다. 엎드려 누운 자세에서 대상자가 아프다고 표현하는 허리부의 중심점에서 측정을 하였다. 3 번 측정하여 평균값을 사용하였다.

\section{(4) 시각통증척도(visual analogue scale, VAS)}

대상자들의 시각통증척도를 측정하기 위하여 0 에서 10 의 숫자평정 척도를 사용하였다. 대상자들은 중재 전 통증 수치를 0 에서 10 사이 의 숫자로 선택하고 중재 후 다시 선택하였다.

\section{3) 분석 방법}

수집된 모든 자료의 통계 처리는 윈도우용 SPSS version 23.0 프로그램 (SPSS Inc., Chicago, IL, USA)을 사용하였다. 통계 방법을 결정하기 위 해 측정된 변수들은 샤피로-윌크 검정의 정규성 검정을 통해 정규성 을 확인하였다. 실험군과 대조군의 군 내 중재 전후 차이를 비교하기 위해 대응표본 t-검정(paired t-test)을 사용하였다. 실험군과 대조군 간 차이를 비교하기 위해 독립표본 t-검정(independent t-test)을 사용하였 다. 통계학적 유의수준 $\alpha$ 는 0.05 로 설정하였다.

\section{결 과}

\section{1. 중재 전후 근 활성도 비교}

슬링 운동군과 부하저항 운동군의 중재 후 근활성도를 보기 위하여 독립표본 $\mathrm{t}$-검정을 실시한 결과, 두 군 모두 넙다리곧은근의 근활성도 는 유의하게 감소하였고 $(\mathrm{p}<0.05)$, 배바깥빗근과 배속빗근의 근활성 도는 유의하게 증가하였다 $(\mathrm{p}<0.05)$ (Table 2). 배곧은근의 경우 슬링 운동 군에서는 유의하게 감소하였으나, 부하저항운동 군에서는 증가 하였다( $<0.05)$. 군 간 변화량의 비교에서는 슬링 운동 군에서 배속 빗근, 배바깥빗근의 변화량이 유의하게 증가하였다 $(\mathrm{p}<0.05)$ (Table 2).

\section{2. 중재 전후 가로면에서의 골반 회전 각도 비교}

두 군의 가로면에서의 골반 회전 각도를 비교한 결과, 슬링 운동 군 내 
Table 2. The comparison of electromyography in each of the groups at pre-post group

(Unit: \%RVC)

\begin{tabular}{lcccccc}
\hline Muscle & Pre & Post & $\begin{array}{c}\text { Difference } \\
\text { value }\end{array}$ & $t$ & $p$ \\
\hline RF & SEG & $162.62 \pm 56.03$ & $102.02 \pm 68.90$ & $-60.60 \pm 38.89$ & 4.927 & $0.001^{*}$ \\
& REG & $193.16 \pm 82.42$ & $98.56 \pm 33.14$ & $-34.05 \pm 38.54$ & 4.728 & $0.001^{*}$ \\
t & & & -1.534 & & \\
p & & & 0.143 & & \\
IO & SEG & $46.81 \pm 22.95$ & $128.83 \pm 75.96$ & $82.02 \pm 69.45$ & -3.735 & $0.005^{*}$ \\
REG & $47.75 \pm 26.66$ & $67.87 \pm 22.56$ & $12.10 \pm 14.27$ & -3.737 & $0.005^{*}$ \\
t & & & 3.119 & & \\
p & & & $0.0111^{*}$ & & \\
EO SEG & $99.13 \pm 45.02$ & $171.55 \pm 94.21$ & $72.42 \pm 80.74$ & -2.836 & $0.020^{*}$ \\
REG & $61.28 \pm 32.88$ & $79.55 \pm 45.80$ & $-2.60 \pm 16.76$ & -2.341 & $0.044^{*}$ \\
t & & & 2.877 & & \\
p & & & $0.017^{*}$ & & \\
RA SEG & $64.71 \pm 17.04$ & $50.15 \pm 23.74$ & $-14.56 \pm 15.87$ & 2.902 & $0.018^{*}$ \\
REG & $37.68 \pm 21.91$ & $17.26 \pm 8.80$ & $1.96 \pm 10.42$ & 3.565 & $0.006^{*}$ \\
t & & & -2.752 & & \\
p & & & & $0.013^{*}$ & &
\end{tabular}

RF: rectus femoris, IO: internal oblique, EO: external oblique, RA: rectus abdominis.

Mean \pm standard

${ }^{*} p<0.05$.

전 후 차이에 유의하게 감소하였다 $(\mathrm{p}<0.05)($ Table 3$)$.

\section{3. 중재 전후 압통 역치 비교}

두 군 모두 중재 후 압통 역치가 유의하게 증가하였다 $(\mathrm{p}<0.05)$ (Table 3). 두 군의 압통 역치 변화량의 차이를 비교 해 본 결과 슬링 운동 군 에서 더 큰 차이를 보였다 $(\mathrm{p}<0.05)$.

\section{4. 중재 전후 시각통증척도 비교}

시각통증척도는 슬링 운동 군에서 유의하게 감소하였다 $(\mathrm{p}<0.05)$. 두 군 간 시각통증척도를 비교 해 본 결과 슬링 운동 군에서 더 큰 감소 를 보였다 $(\mathrm{p}<0.05)($ Table 3$)$.

\section{고 찰}

본 연구는 저강도 슬링 운동과 고강도 부하저항운동이 만성 허리통 증 환자의 능동뻗은발올림검사 동안 근활성도, 가로면에서의 골반 회전 각도와 압통 역치, 시각통증척도에 즉각적으로 미치는 영향을 비교하고자 하였다.

능동뻗은발올림 동안 근활성도를 비교한 결과, 중재 후 두 운동 모 두 배바깥빗근과 배속빗근의 근활성도가 유의하게 증가되었다. $\mathrm{Ng}$ 등 19 은 허리 통증 환자가 정상인에 비해 몸통 회전 동안 최대근력이 낮아지고, 뭇갈래근, 배바깥빗근, 배곧은근의 근활성도가 낮았다고
Table 3. The comparison of pelvic rotation angle, pain press threshold and visual analogue scale in each of the group at pre-post group

(PRA unit: degree, PPT unit: kg)

\begin{tabular}{cccccc}
\hline & Pre & Post & $\begin{array}{c}\text { Difference } \\
\text { value }\end{array}$ & t & $p$ \\
\hline PRA SEG & $13.15 \pm 3.58$ & $7.55 \pm 2.46$ & $-5.60 \pm 2.99$ & 5.919 & $0.000^{*}$ \\
REG & $11.30 \pm 3.53$ & $9.97 \pm 3.20$ & $-3.23 \pm 2.40$ & 2.033 & 0.073 \\
t & & & -1.952 & & \\
p & & & 0.067 & & \\
PPT SEG & $5.41 \pm 1.08$ & $8.40 \pm 2.66$ & $2.99 \pm 2.98$ & -3.176 & $0.011^{*}$ \\
REG & $5.62 \pm 1.06$ & $7.93 \pm 1.60$ & $0.63 \pm 0.91$ & -5.339 & $0.000^{*}$ \\
t & & & 2.398 & & \\
p & & & $0.036 *$ & & \\
VAS SEG & $5.00 \pm 1.15$ & $2.40 \pm 1.07$ & $-2.60 \pm 1.26$ & 6.500 & $0.000^{*}$ \\
REG & $5.10 \pm 0.88$ & $5.20 \pm 1.14$ & $0.10 \pm 1.29$ & -0.246 & 0.811 \\
t & & & -4.732 & & \\
p & & & $0.000 *$ & & \\
\hline
\end{tabular}

PRA: pelvic rotation angle, PPT: pain press threshold, VAS: visual analogue scale. Mean \pm standard

${ }^{*} p<0.05$.

보고하였다. Kang 등 ${ }^{20}$ 은 허리 통증 환자를 대상으로 한 슬링 교각 운 동이 배속빗근을 유의하게 증가시켰다고 보고하였다. Kong ${ }^{21}$ 은 진동 을 겸한 슬링 운동치료 기법이 배가로근, 배속빗근 등의 심부 근육의 활성화를 증가시키고 초음파상 근육 두께가 유의하게 증가하였다고 보고하였다. 또한 Kirkesola'는 만성 허리통증 환자에게 슬링 운동이 배가로근, 배바깥빗근, 배속빗근을 자극하여 몸통 안정성을 만들어 허리 통증을 효과적으로 줄일 수 있다고 보고하였다. Choi와 Kang ${ }^{22}$ 은 본 연구와 같은 자세인 진동을 겸한 슬링의 엎드린 교각 운동이 진 동이 없는 슬링의 엎드린 교각 운동보다 더 많은 배속빗근의 근활성 도 증가를 한다고 보고하였다. 또 만성 허리 통증 환자에게 슬링 운동 이 배속빗근, 배바깥빗근의 근활성도를 증가시킨다는 선행연구들이 있다. ${ }^{23} \mathrm{Bressel}$ 등 ${ }^{24}$ 은 감독하에 시행된 부하저항운동이 배바깥빗근, 배속빗근, 배가로근의 표면 근활성도를 유의하게 증가시킨다고 보고 했다. 이는 두 운동 모두 능동뻗은발올림 동안 배바깥빗근과 배속빗 근의 근활성도 증가로 하지의 움직임에 대한 몸통 안정성에 기여한 것으로 보인다.

슬링 운동 군에서 배곧은근의 근활성도는 유의하게 감소하였다. Kong과 Hwang 5 은 몸통이 불안정한 환경에서 심부근 활성도가 증가 되고 배곧은근과 허리네모근 등의 표면근의 활성도는 낮아진다고 보 고하였다. Falla와 Hodges"는 심부근의 근활성도가 증가하면 표면근 의 근활성도는 감소한다고 하였다. 이것은 슬링 운동이 심부근 활성 도를 증가시킨 결과로 배곧은근의 활성도가 유의하게 감소한 것으로 사료된다. 반면 부하저항운동 군에서는 배곧은근의 근활성도는 유 의하게 증가하였다 $(\mathrm{p}<0.05)$. 본 연구에서 부하저항운동은 몸통 회전 움직임에 초점이 맞추어진 저항운동으로 넓은등근, 배곧은근, 배바 
깥빗근, 배속빗근 등의 표면근과 회전근을 자극하였다. 허리 통증 환 자가 회전 운동을 하게 되면 높은 굴곡 결합 토크가 측정된다는 선행 연구와 같은 결과를 나타낸다. ${ }^{19}$ 또한 Bressel 등 24 은 감독하에 시행된 부하저항운동이 배곧은근의 근활성도가 유의하게 증가시킨다고 보 고하였다. 이것은 허리 통증 환자들이 회전 운동을 하였을 때 통증이 증가되지 않는 범위에서 운동을 하였음에도 불구하고 통증이 있는 허리근육 보다 몸통 굴곡근을 더 많이 사용하여 회전 운동을 하는 것 때문으로 사료된다.

두 운동 모두 넙다리곧은근의 근활성도가 유의하게 감소하였다. 선행연구에서 허리 통증이 있는 환자는 시상면의 움직임 동안 근육 활성화 순서에 몇가지 변화를 보고하였다..$^{17}$ Cowan 등 25 은 통증 환자 들의 능동뻗은발올림 동안 배가로근의 지연 수축을 확인한 바 있다. 또한 Boyd-Clark 등 26 은 16 명의 통증 환자에게 유의한 차이를 보이며 심부근의 억제 및 감소가 표면근의 과활성화와 함께 발생한다는 보 고를 하였다. Nelson-Wong 등근 다리를 들어올리는 동안 정상군은 근위부-원위부 순서로 근수축을 하게 되지만, 통증이 있는 환자는 원위부-근위부 순서로 근수축을 하게 된다고 보고하였다. 또 선행연 구에서 인위적으로 만든 통증은 즉각적으로 최대 자발적 등척성 수 축을 감소 시킨다는 것을 확인하였다. 또한 여러 선행연구에서 통증 환자는 먼쪽 분절의 움직임이 있을 경우 부족한 몸통의 안정성을 보 상하기 위하여 먼쪽 분절 근육의 활성도를 높혀 보상을 하게 된다고 보고한 결과와 유사하다.6,1725 Kong과 Hwang ${ }^{5}$ 은 사지가 움직일 때 먼 쪽 분절에서의 수축이 배속빗근, 척추세움근, 중간볼기근, 배바깥빗 근의 근활성도를 낮춘다고 보고 하였다. 이는 두 운동 군 모두 증가된 몸통 근육의 근활성도가 몸통 안정성을 유지시켜 먼쪽 분절에서의 보상작용을 줄여 넙다리곧은근의 근활성도를 유의하게 감소한 것과 일치하는 것으로 사료된다.

능동뻗은발올림 동안 골반 회전 각도 변화를 비교한 결과, 슬링 운 동 군에서 유의하게 감소하였다. Liebenson 등10은 증가된 몸통 근활 성도가 능동뻗은발올림 동안 골반의 안정성을 유지시켜 골반의 움 직임을 줄였다는 것을 발견하였다. 또한 Ota 등 27 은 재활 초기 몸통의 소근육군의 기능 증진에 초점이 맞춰진 즉각적인 복부 드로우인을 한 상태로 보행을 하게 되면 등척주 뒤굽음 각이 감소하여 체중중심 선의 지레 팔이 감소하여 허리 근육의 과한 긴장감을 줄여 허리-골반 조절력을 증가시킬 수 있다고 보고하였다. 선행연구에서 배속빗근과 배바깥빗근이 능동뻗은발올림 동안 몸통을 지지하고 고정하여 엉 덩관절 조절을 하는 핵심적인 근육임을 증명하였다. ${ }^{28}$ Graven-Nielsen 등 29 은 통증이 생기면 두뇌가 통증부 근육으로 신호 출력을 감소시 키고, 최대근수축력을 줄인다고 보고하였다. 능동뻗은발올림 동안 몸통 근육으로 신호 출력이 감소하면 하지 근육이 보상 패턴을 시작 하며 골반의 회전이 일어나는 것으로 보인다. 다양한 선행 연구에서
실험적으로 유발된 통증이 움직임 동안 운동 조절의 핵심 전략을 변 화시킨다는 것을 보여주었다. ${ }^{30,31}$ 허리 통증에 의해 핵심적인 근육 조 직에서 충분한 조정이 이루어지지 않으면 보상 패턴이 생겨 몸통-골 반 협응을 적절히 조절하지 못한다. ${ }^{32}$ 능동뻗은발올림 동안 허리통증 환자에게 골반의 전방 경사가 증가된 많은 선행 연구들이 있다. 하지 만 허리-골반 조절의 지표 중 하나인 골반 회전각에 대한 선행 연구 는 다양하지 않다. 본 연구의 결과를 통해 슬링 운동이 부하저항운동 에 보다 능동뻗은발올림 동안 즉각적으로 몸통 근육을 올바르게 조 절하고 보상 패턴을 줄여 골반의 회전을 조절하는데 도움을 준다고 해석된다. 따라서 허리통증 환자의 재활초기에 억제된 근육의 운동 재학습은 근력 강화보다 더 중요할 수 있다는 선행 연구 ${ }^{8}$ 와 의견이 같다.

시각통증척도의 경우 슬링 운동 군에서 유의하게 감소하였다. 진 동을 이용한 슬링 운동치료가 즉각적으로 통증을 감소시킨다는 선 행 연구와 같은 결과를 나타내고 있다.921 또 만성 허리 통증 환자에게 슬링 운동이 통증을 줄이고 허리 기능을 증가시키는데 효과적이라 고 하는 선행 연구와도 비슷한 결과를 나타낸다. ${ }^{33}$ 또한 Kim 등 ${ }^{34}$ 은 만성 허리통증 환자에게 40 분간의 Neurac 슬링 운동이 시각 통증 척 도 수치를 유의하게 감소하였다고 보고하였다. 또 Vasseljen 등 35 은 만 성 허리 통증 환자에게 슬링을 이용한 중재를 통해 허리 통증이 감소 되는 것을 확인하였다. 이것은 Neurac을 이용한 슬링 운동이 일반적 인 몸통 회전 근력 운동보다 효과적으로 즉각적인 통증 제어를 하는 것으로 사료된다. Falla와 Hodges"는 만성 척추 통증 환자에게 일반적 인 저항운동은 통증에 큰 영향을 주지 못한다는 결론이 놀랄 일이 아니라고 하였다. $\mathrm{Kim}$ 등 36 도 허리 통증으로 인해 소근육군의 기능 장애를 가진 대상자들에게 대근육군과 분리된 움직임을 이끌어내 며 정확한 훈련을 시행하는 것은 다소 어려움이 있다고 토로했다. 하 지만 $\operatorname{Kim}$ 등 ${ }^{36}$ 은 슬링 운동의 경우 불안정한 환경에 노출되어진 운동 으로 무의식적으로 안정화에 더 많은 기여를 한 것으로 판단하였다. 하지만 8 주 이상의 부하저항운동은 허리 통증을 유의하게 감소시킨 다는 선행 연구가 있다. 33,35 이는 재활초기 적용되는 부하저항운동은 슬링에 비해 고유수용성 감각 자극에 불리하여 즉각적으로 통증을 감소시키는데 부적합하다고 사료된다.

압통 역치는 두 군 모두 유의하게 증가하였다. 압통 역치는 근피로 가 높을 수록 낮아진다. ${ }^{37} \mathrm{Kong}$ 과 Hwang ${ }^{5}$ 은 몸통 안정성이 확보되면 허리네모근의 근활동이 감소된다고 보고하였다. 이는 두 운동 모두 배바깥빗근과 배속빗근의 근활성도를 증가시켰기 때문에 상호억제 (reciprocal inhibition)에 의해 허리네모근의 근활성도를 상대적으로 낮추어 근피로를 줄여 압통 역치가 높아진 것으로 사료된다.

두 운동을 통한 결과를 비교해보면 슬링 운동이 즉각적인 통증 조 절과 능동뻗은발올림 동안의 골반 조절에 더 뛰어난 것으로 보인다. 
하지만 선행 연구에서 8주간 지속 된 슬링 운동과 일반적 근력 운동 이후에는 통증, 장애, 체간 유연성에서 두 운동 간의 유의한 차이는 없었다고 보고하였다. ${ }^{31}$ 따라서 재활 초기에는 일반적인 근력 운동보 다 슬링 운동으로 허리통증 환자의 중재를 하는 것이 통증 조절과 몸 통 안정화근의 활성화 및 적절한 허리-골반 안정성 조절에 도움이 된 다고 볼 수 있다. 재활 초기에 슬링 운동을 먼저 적용한 후 통증이 감 소되면 근력 강화 운동을 적용할 것을 추천한다.

본 연구의 제한점은 첫째, 표면근전도기기의 사용으로 심부근의 근활성도를 직접 측정하기 어려웠다. 선행 연구에서 제시한 통증이 있는 대상자들의 심부근 활성화 지연을 확인하지 못 하였다. 통증이 근육을 지연 수축 시킨다는 것을 측정 하였다면 올바른 근수축 타이 밍을 위해 운동 프로그램을 조절 하고 제시하는데 도움이 되었을 것 이다. 둘째, 단면 연구였기 때문에 장기적으로 통증, 근활성도, 골반 회전 각도가 어떻게 변하는지 파악하기 어려웠다. 중재 직후 근활성 도의 변화에 대한 차이를 볼 수는 있으나 이 차이를 운동 학습의 결 과로 나타난 차이로 설명하기 어려웠다. 따라서 향후 연구에서 이를 보완하기 위하여 근 수축 타이밍을 측정하는 연구와 더불어 8 주 이 상의 중재를 가진 실험이 이루어져야 할 것이다.

\section{참고문헌}

1. Schwarzer AC, Wang S, Bogduk N et al. Prevalence and clinical features of lumbar zygapophysial joint pain: a study in an Australian population with chronic low back pain. Ann Rheum Dis. 1995;54(2):100-6.

2. Yahia A, Jribi S, Ghroubi S et al. Evaluation of the posture and muscular strength of the trunk and inferior members of patients with chronic lumbar pain. Joint Bone Spine. 2011;78(3):291-7.

3. Han JS, Cho WS, Lim JH. The effects of Pilates mat exercise on trunk muscle thickness and balance. J Kor Phys Ther. 2017;29(4):201-6.

4. Boyd-Clark LC, Briggs CA, Galea MP. Muscle spindle distribution, morphology, and density in longus colli and multifidus muscles of the cervical spine. Spine. 2002;27(7):694-701.

5. Choi Y, Kang H. The effects of sling exercise using vibration on trunk muscle activities of healthy adults. J Phys Ther Sci. 2013;25(10):1291-4.

6. Ota S, Kano R, Fukuta S et al. Acute influences of draw-in maneuver for spine alignment and knee adduction moment during gait. Osteoarthritis and Cartilage. 2015;23(2):122.

7. Ellenbecker TS, Roetert EP. An isokinetic profile of trunk rotation strength in elite tennis players. Med Sci Sports Exerc. 2004;36(11):1959-63.

8. Unsgaard-Tøndel M, Fladmark AM, Salvesen $\emptyset$ et al. Motor control exercises, sling exercises, and general exercises for patients with chronic low back pain: a randomized controlled trial with 1-year follow-up. Phys Ther. 2010;90(10):1426-40.

9. Kirkesola G. Neurac-a new treatment method for long-term musculoskeletal pain. The Journal Fysioterapeuten. 2009;76(12):16-25.

10. Liebenson C, Karpowicz M, Brown HM et al. The active straight leg raise test and lumbar spine stability. PM R. 2009;1(6):530-5.
11. Kim JH, Suh HR, Kim CY et al. Influence of difficulty variation of the core stabilization exercise on thickness changes of abdominal muscles in healthy subjects: a pilot study. J Kor Phys Ther. 2016;28(2):112-8.

12. Bak JW, Shim SY, Cho MK et al. The effect of plank exercises with hip abduction using sling on trunk muscle activation in healthy adults. J Kor Phys Ther. 2017;29(3):128-34.

13. Falla D, Hodges PW. Individualized exercise interventions for spinal pain. Exerc Sport Sci Rev. 2017;45(2):105-15.

14. Hermens HJ, Freriks B, Disselhorst-Klug C et al. Development of recommendations for SEMG sensors and sensor placement procedures. J Electromyogr Kinesiol. 2000;10(5):361-74.

15. Cram JR, Kasman GS, Holtz J. Introduction to surface electromyography. Gaithersburg, Aspen Publishers, 1998.

16. Dankaerts W, O'sullivan PB, Burnett AF et al. Reliability of EMG measurements for trunk muscles during maximal and sub-maximal voluntary isometric contractions in healthy controls and CLBP patients. J Electromyogr Kinesiol. 2004;14(3):333-42.

17. Nelson-Wong E, Poupore K, Ingvalson S et al. Neuromuscular strategies for lumbopelvic control during frontal and sagittal plane movement challenges differ between people with and without low back pain. J Electromyogr Kinesiol. 2013;23(6):1317-24.

18. Winter DA. Biomechanics and motor control of human movement. Hoboken, John Wiley \& Sons, Inc, 2009.

19. Graven-Nielsen T, Lund, H, Arent-Nielsen L et al. Inhibition of maximal voluntary contraction force by experimental muscle pain: a centrally mediated mechanism. Muscle Nerve. 2002;26(5):708-12.

20. Akuthota V, Ferreiro A, Moore T et al. Core stability exercise principles. Curr Sports Med Rep. 2008;7(1):39-44.

21. Lamoth CJC, Daffertshofer A, Meijer OG et al. How do persons with chronic low back pain speed up and slow down? Gait Posture. 2006; 23(2): 230-9.

22. Bressel E, Willardson JM, Thompson B et al. Effect of instruction, surface stability, and load intensity on trunk muscle activity. J Electromyogr Kinesiol. 2009;19(6):500-4.

23. Cowan SM, Schache AG, Brukner P et al. Delayed onset of transversus abdominus in long-standing groin pain. Med Sci Sports Exerc. 2004; 36(12):2040-5.

24. Kong YS, Hwang YT. Effect of power grasping on muscle activity of trunk during one leg stance. J Kor Phys Ther. 2017;29(2):91-4.

25. Ng JK, Richardson CA, Parnianpour M et al. EMG activity of trunk muscles and torque output during isometric axial rotation exertion: a comparison between back pain patients and matched controls. J Orthop Res. 2002;20(1):112-21.

26. Kang H, Jung J, Yu J. Comparison of trunk muscle activity during bridging exercises using a sling in patients with low back pain. J Sports Sci Med. 2012;11(3):510-5.

27. Kim JH, Kim YE, Bae SH et al. The effect of the Neurac sling exercise on postural balance adjustment and muscular response patterns in chronic low back pain patients. J Phys Ther Sci. 2013;25(8):1015-9.

28. Ervilha UF, Farina D, Arent-Nielsen L et al. Experimental muscle pain changes motor control strategies in dynamic contractions. Exp Brain Res. 2005;164(2):215-24.

29. Madeleine P, Mathiassen SE, Arent-Nielsen L. Changes in degree of motor variability associated with experimental and chronic neck-shoulder 
pain during a standardized repetitive arm movement. Exp Brain Res. 2008;185(4):689-98.

30. Kim TH. Factors influencing pelvic and trunk motions during one-leg standing. Yonsei University. Dissertation of Doctorate Degree. 2010.

31. Kibler WB, Press J, Sciascia A. The role of core stability in athletic function. Sports Med. 2006;36(3):189-98.

32. Persson AL, Hansson GA, Kalliomäki A et al. Pressure pain thresholds and electromyographically defined muscular fatigue induced by a muscular endurance test in normal women. Clin J Pain. 2000;16(2):155-63.

33. Vasseljen O, Unsgaard-Tøndel M, Westad C et al. Effect of core stability exercises on feed-forward activation of deep abdominal muscles in chronic low back pain: a randomized controlled trial. Spine. 2012;37(13):1101-8.

34. Park J, Lee S, Hwangbo G. The effects of a bridge exercise with vibration training and an unstable base of support on lumbar stabilization. J Phys Ther Sci. 2015;27(1):63-5.

35. Kim MK, Cho YH, Park JW et al. The effects of the contraction degree of hip joint adductor on abdominal muscle activity during bilateral lower extremity raising. J Kor Phys Ther. 2016;28(3):217-20.

36. Koumantakis GA, Watson PJ, Oldham JA. Trunk muscle stabilization training plus general exercise versus general exercise only: randomized controlled trial of patients with recurrent low back pain. Phys Ther. 2005; 85(3):209-25.

37. Kong KW. Effects of bridging exercise using vibration stimulation and ADIMs on the lengthening and thickness of transversus abdominis in healthy adults. J Kor Phys Ther. 2016;28(6):393-7. 